\title{
The use of three dye-binding procedures for the assessment of heat damage to food proteins*
}

\author{
By R. F. HURRELL AND K. J. CARPENTER \\ Department of Applied Biology, University of Cambridge, \\ Cambridge $C B 2{ }_{3} D X$ \\ (Received I8 fune I974-Accepted 2 fuly r974)
}

\begin{abstract}
I. A study has been made of pure proteins heated either alone or in contact with sugars, so as to cause a severe fall in their reactive lysine contents, and also of commercial protein concentrates.

2. For unheated materials, and for bovine plasma albumin and fat-extracted, dried chicken muscle severely heated in the absence of sugar, Acid Orange 12 binding values (mmol bound dye/kg crude protein (nitrogen $\times 6.25$ )) were close to the sum of total histidine, total arginine and reactive lysine contents (mmol $/ \mathrm{kg}$ crude protein $(\mathrm{N} \times 6.25)$ ), which we have termed HARL values. The dye-binding values and the HARL values were reduced similarly by heat treatment.

3. For materials in which protein and glucose had reacted under mild conditions $\left(37^{\circ}\right)$, the dye-binding capacity with Acid Orange 12 was unchanged even though the HARL value of these materials was considerably reduced. When protein and glucose or sucrose were heated more severely, the dye-binding capacity was slightly lowered but not to the same extent as the reduction in the basic amino acids.

4. Animal feeding-stuffs, whether unheated, industrially processed or deliberately heated, appeared to react with Acid Orange 12 in the same way as the model systems (selected to represent three types of heat damage: 'advanced' and 'early' Maillard and protein-protein damage).

5. Remazol blue binding values and fluorodinitrobenzene (FDNB)-reactive lysine values were similarly reduced in materials that had been severely heated, either with or without added sugars; however, when protein and glucose had reacted under mild conditions the fall in Remazol blue binding was less than that in FDNB-reactive lysine.

6. For the model materials, binding with cresol red was, in general, higher for heated samples but the results showed no correlation with FDNB-reactive lysine values. For meat and groundnut meals, changes in values after heat treatment were smaller than those that have been reported for soya-bean meals.
\end{abstract}

Dye-binding procedures are rapid and inexpensive methods of analysis which can be successfully semi-automated and, as pointed out by Lakin (1973), they would be very useful in the food and feeding-stuffs industries if they could be applied to monitor the extent of heat damage to proteins in processed foods.

The dyes which seem particularly convenient for this purpose are the acid azo dyes; they combine at low $\mathrm{pH}$ with the basic groups of lysine, histidine and arginine units and with the terminal amino groups of protein chains (Fraenkel-Conrat \& Cooper, 1944). The amount of dye bound depends on the level of protein in the sample and on its content of basic groups. If the nature of the protein remains constant, the amount of dye bound depends on the quantity of protein in the samples and, so far, the main use for dye-binding procedures has been for the estimation of crude-protein (nitrogen $\times 6 \cdot 25$ ) content, e.g. in wheat (Udy, 1954, 1956), soya bean

* Some results have been reported in a preliminary form (Hurrell \& Carpenter, 1974a). 
(Pomeranz, I965) and milk (Ashworth \& Chaudry, 1962). It is, of course, necessary to calibrate separately for different food materials because each material has its own characteristic amino acid pattern.

For a fixed level of $\mathrm{N}$ the amount of dye bound depends on the number of reactive groups in the protein. This has been used as an indicator of protein quality in plantbreeding studies where barleys (Hagberg \& Karlsson, I968; Mossberg, 1968) as well as other cereals, pulses and millets (Kaul, Dhar $\&$ Raghaviah, $197^{\circ}$ ) have been screened to select strains of high basic amino acid content, which has correlated with high lysine content. Dye-binding procedures with azo dyes may also be of use as an indicator of nutritional damage during heat treatment, as lysine can combine through its $\epsilon$-amino group to form nutritionally unavailable derivatives and these may result in reduced dye binding by the lysine units. This has not been investigated systematically although there are many reports that the dye-binding capacity (DBC) of food proteins is reduced by heating (Bunyan \& Price, I960; Moran, Jensen \& McGinnis, 1963; Mossberg, i966).

The reactive dye, Remazol brilliant blue, was used by Ney \& Wirotama (I970) as an indicator of the available-lysine content of milk products, and the phthalein dye, cresol red, has been used to monitor the heat treatment given to soya-bean meals (Frölich, 1954). We have chosen these dyes and Acid Orange 12, as an example of an azo dye, and studied their value for measuring the different types of heat damage to protein in model materials (selected to represent three types of heat damage: 'advanced' and 'early' Maillard and protein-protein damage). In addition, we have measured the Acid Orange 12 and cresol red binding of some commercial protein concentrates.

We have followed other workers in using the term 'dye binding capacity' (DBC) while accepting that our values refer to the degree of dye binding that has occurred under standard conditions of limited duration.

\section{EXPERIMENTAL}

\section{Test materials}

Model materials. Bovine plasma albumin (BPA), solvent-extracted chicken muscle and albumin-sugar mixes, all heated and unheated, were the same materials as those used in a previous study of different analytical procedures for measuring reactive lysine (Hurrell \& Carpenter, 1974b). In addition further chicken muscle and BPA samples were prepared, as before, by autoclaving at $12 \mathrm{I}^{\circ}$ in sealed glass ampoules.

Lactalbumin X844, formyl lactalbumin and propionyl lactalbumin 2 were the same materials as those used by Bjarnason \& Carpenter(1969). Formyl lactalbumin and propionyl lactalbumin 2 were shown to have 75 and $97 \%$ respectively of their lysine $\epsilon$-amino groups in a form that would not give a reaction with fluorodinitrobenzene (FDNB).

Commercial protein concentrates. The animal carcass products were the same materials as those used by Atkinson \& Carpenter (1970). The blood meals (X 949 and X 953) were obtained from the Van Hoven Co., South St Paul, Minnesota, USA, and they had been dried at low and high temperatures respectively. 
Acid Orange 12

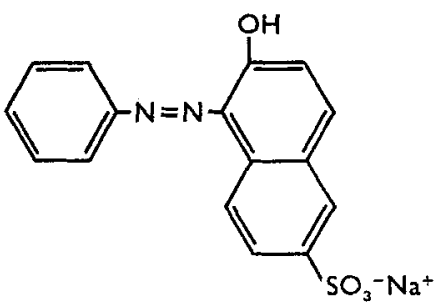

Remazol Brilliant Blue $\mathrm{R}$
Cresol red

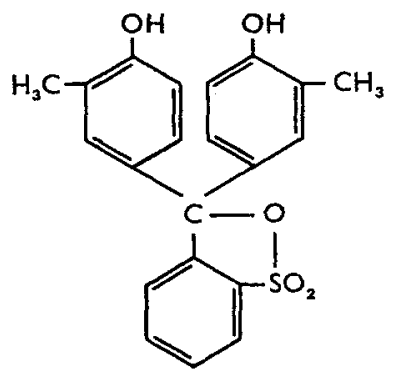<smiles>Nc1c([N+](=O)[O-])cc(Nc2cccc([N+](=O)OCCOCO[NH3+])c2)c2c1C(=O)c1ccccc1C2=O</smiles>

Fig. I. Structure of dyes used in the three dye-binding procedures for the assessment of heat damage to food proteins.

Fish meal $\mathrm{Z}_{4}$ was a capelin press cake meal, $\mathrm{Z} 6$ was the same meal with $400 \mathrm{~g}$ added 'solubles' $/ \mathrm{kg}$ and $\mathrm{Z} 8$ was a commercial capelin meal chosen because of its relatively low FDNB-reactive lysine value. These came from the Herring Oil and Meal Research Institute, Bergen, Norway. $Z Z_{2}$ and $Z 33$ were commercial Danish fish meals investigated by us because of their relatively low FDNB-lysine value, and D 700 was a solvent-extracted herring flour.

Groundnut meal Z 9 was obtained from Spillers Ltd, Cambridge, and portions of it were autoclaved at $12 \mathrm{I}^{\circ}$ in sealed aluminium-foil packets $(460 \mathrm{~mm} \times 300 \mathrm{~mm} \times 25$ $\mathrm{mm}$ ) for I and $4 \mathrm{~h}$ respectively. Groundnut-protein isolate $X_{3} 68$ was obtained from the Central Food Technological Research Institute, Mysore, India; it had been prepared as described by Anantharaman \& Carpenter (197I) for sample X 542.

Milk powder X 173 had been stored in a sealed container at room temperature for approximately 29 years.

\section{Analytical methods}

Nitrogen and direct FDNB-reactive lysine. These were determined using methods described by Hurrell \& Carpenter (1974 b). The 'FDNB' procedure (Carpenter, I960; as modified by Booth, I97I) measures non- $\mathrm{N}$ terminal lysine and hydroxylysine units in peptide chains, but not the corresponding free amino acids. However, for convenience, the values will be described in the test simply as 'reactive lysine'.

Total histidine and arginine. The test materials $(200-400 \mathrm{mg})$ were refluxed for $16 \mathrm{~h}$ with $420 \mathrm{ml} 6 \mathrm{M}-\mathrm{HCl}$. Histidine and arginine were determined in the hydrolysates by the method of Spackman, Stein \& Moore (1958) using a Technicon AutoAnalyzer (Technicon Ltd, Basingstoke, Hants) with a $150 \mathrm{~mm}$ column. L- $\alpha$-amino- $\beta$ guanidinopropionic acid was used as the internal standard.

The 'reactive basic amino acid content' of each material was calculated as the sum of its total histidine, total arginine and reactive lysine (+ hydroxylysine) values and 
has been termed the HARL value. This still excludes terminal amino groups, which are relatively unimportant with ordinary protein material.

Acid Orange $\mathrm{I} 2$ binding. Dye-binding measurements were made with a solution of Acid Orange 12 (Fig. I) ready-mixed for use with a Pro-Meter Mk II (A/S N Foss Electric, Hillerød, Denmark). The apparatus and method were slightly improved versions of that described by Mossberg (1965) for Acid Orange 12, and both the dye, in solution in oxalic acid-acetic acid-phosphate buffer $(\mathrm{pH} \mathrm{I} \cdot 25)$, and the reference standard were supplied by the manufacturers. A quantity of finely ground sample containing ${ }^{12-1} 5 \mathrm{mg} \mathrm{N}$ was placed in the reaction chamber with $40 \mathrm{ml}$ dye solution $(3.89 \mathrm{mmol} / \mathrm{l})$ and a steel disc. After violent shaking for $6 \mathrm{~min}$ the dye-sample mixture was filtered and the extinction of the filtrate was compared with that of the unreacted dye solution and recorded as mmol bound dye/l.

Remazol blue binding. The procedure was that of Pruss \& Ney (I972) with only minor alterations, and a constant protein:dye ratio was maintained throughout the experiment to overcome their finding that dye binding is greatly affected by changes in this ratio. Remazol Brilliant Blue $\mathrm{R}$ (Hoechst AG, Frankfurt) (Fig. I) was dissolved in $0.5 \mathrm{M}$-borate buffer $(\mathrm{pH} \quad 0.8)(2 \mathrm{~g}$ in $200 \mathrm{ml})$ and heated for I $\mathrm{h}$ at $35^{\circ}$ to convert it to the activated vinyl form:

$$
\text { DYE- } \mathrm{SO}_{2} \mathrm{CH}_{2} \mathrm{CH}_{2} \mathrm{OSO}_{3} \mathrm{Na}+\mathrm{NaOH} \longrightarrow \mathrm{DYE}-\mathrm{SO}_{2} \mathrm{CH}=\mathrm{CH}_{2}+\mathrm{Na}_{2} \mathrm{SO}_{4}+\mathrm{H}_{2} \mathrm{O} \text {. }
$$

After cooling, the $\mathrm{pH}$ was adjusted to 8 with $\mathrm{HCl}$ and the volume made up to $500 \mathrm{ml}$. A sample containing $c .16 \mathrm{mg} \mathrm{N}$ was heated with $50 \mathrm{ml}$ activated dye solution for $2 \cdot 5 \mathrm{~h}$ at $60^{\circ}$. The mixture was cooled, filtered and made up to $100 \mathrm{ml}$ with water and I $\mathrm{ml}$ of filtrate was transferred to a $150 \mathrm{~mm} \times 9 \mathrm{~mm}$ column of Sephadex G25 coarse resin and eluted with $0.25 \mathrm{M}$-borate buffer of $\mathrm{pH} 8$. The buffer front containing the dye bound to the soluble protein was eluted after $10 \mathrm{~min}$ and discarded. The unbound dye moved more slowly and was eluted over the next $2 \mathrm{~h}$. When this was complete the eluate was made up to $500 \mathrm{ml}$ and its extinction at $280 \mathrm{~nm}$ measured. The amount of bound dye was calculated by comparing the extinction of the eluate with that of different dilutions of the original activated dye solution in $\mathrm{pH} 8$ buffer. This was converted into mmol by assuming that our sample was the pure compound with a molecular weight of 626 .

Cresol red binding. The structure of cresol red is shown in Fig. I and the procedure used was that of Frölich (1954). 'Test material (200-400 mg), to contain approximately $200 \mathrm{mg}$ crude protein, was weighed into a $50 \mathrm{ml}$ centrifuge tube and $10 \mathrm{ml}$ freshly mixed reagent solution (alcoholic solution of cresol red (BDH Chemicals Ltd, Poole, Dorset) $(2 \mathrm{mg} / \mathrm{ml})$ in $0 . \mathrm{I} \mathrm{M}-\mathrm{HCl}(\mathrm{I}: 9, \mathrm{v} / \mathrm{v}))$ were added. The tube was shaken for $\mathrm{I} \mathrm{h}$ and then centrifuged. After adding $\mathrm{I} \mathrm{ml}$ of the supernatant fraction to Io $\mathrm{ml} 0.02$ $\mathrm{M}-\mathrm{NaOH}$, the extinction at $570 \mathrm{~nm}$ was measured. The amount of bound dye was calculated using a calibration curve of extinction $v$. concentration. 
Vol. 33

Dye binding by heat-damaged proteins

I05

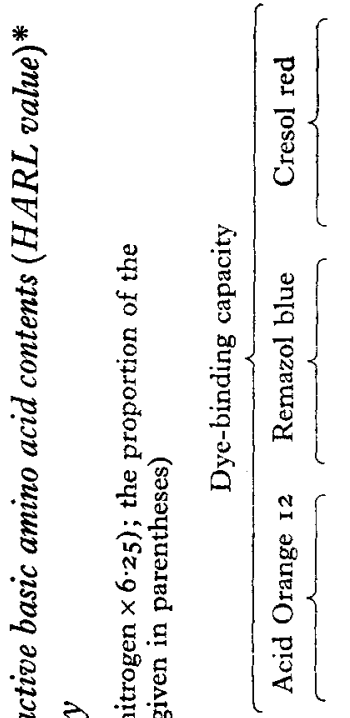

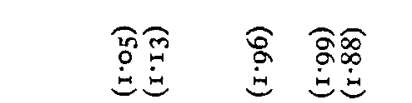

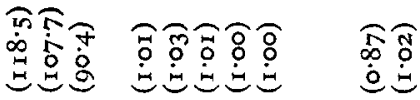

峜

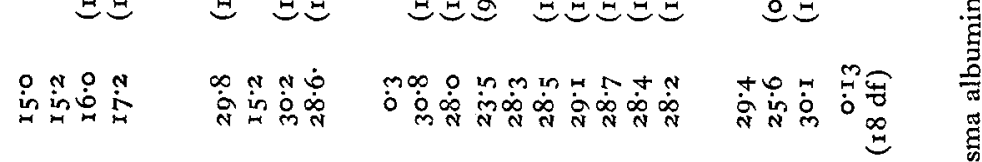

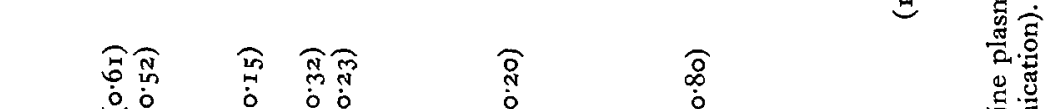

$80^{\circ}$

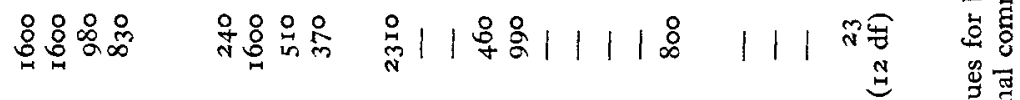

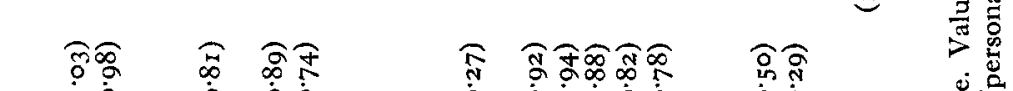

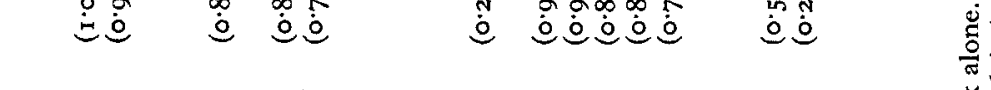

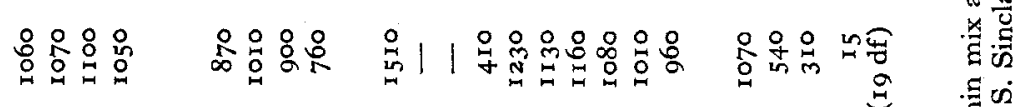

政

청

है है:

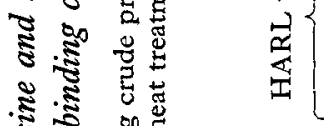

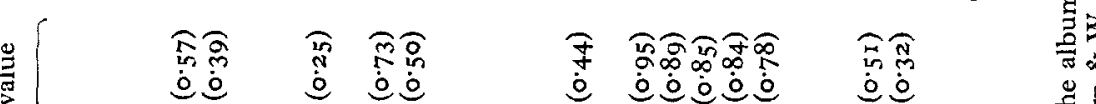

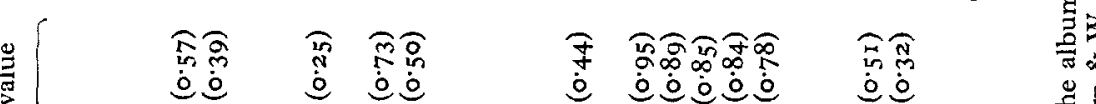

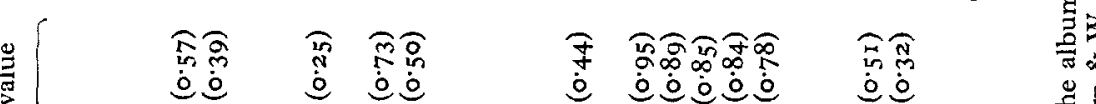

的

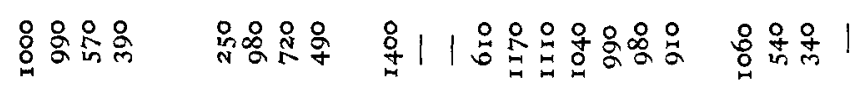

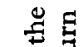

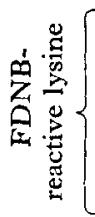

胥

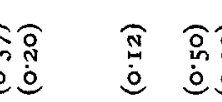

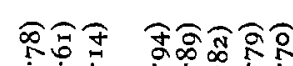

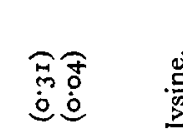

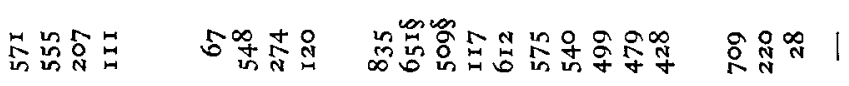

焉葶

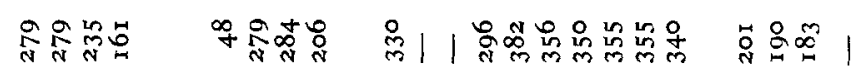

焉.

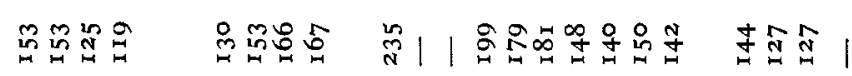
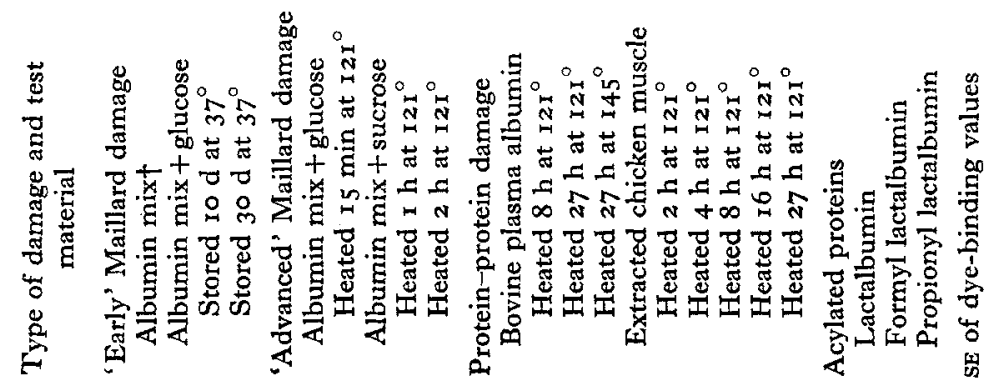

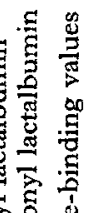




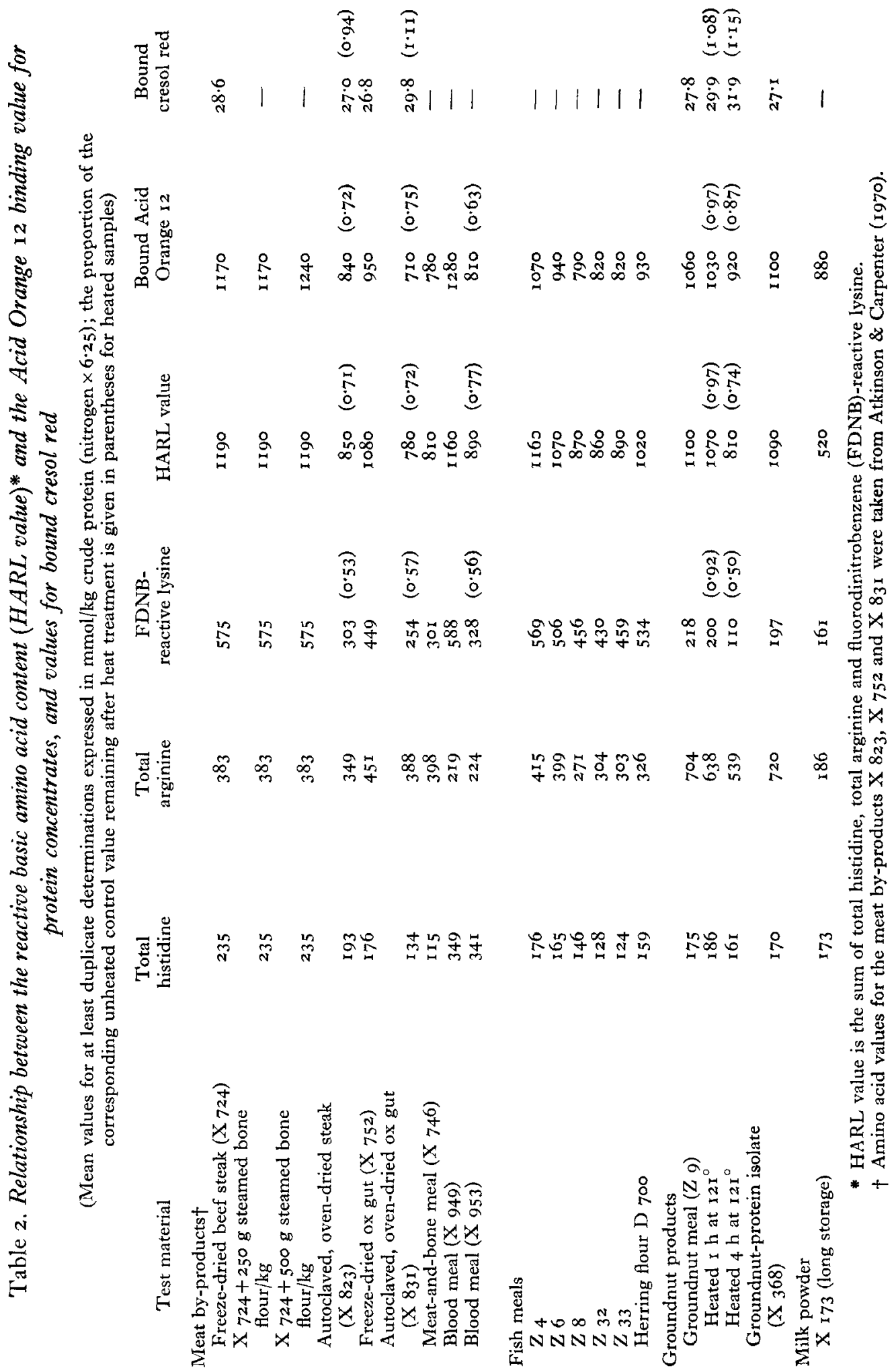




\section{RESULTS}

The model systems were chosen to represent three different types of heat damage (Hurrell \& Carpenter, 1974b) and they are classified as such in Table I, which summarizes our results with these materials. The presence of added sugars in the unheated samples was found not to interfere with the determinations. Further results with protein concentrates are set out in Table 2. Each value is the mean of at least duplicate determinations and for each dye-binding procedure a pooled estimate of the standard error of each result was calculated and is given in Table $\mathrm{I}$.

The results for cresol red were obtained with the dye:protein ratio used by Frölich (1954) in his work with soya-bean meals. For some of our samples the binding was such that a high proportion of the dye was absorbed. Repeating the determinations with smaller quantities of test material gave much higher values $(\mathrm{mmol} / \mathrm{kg}$ crude protein $(\mathrm{N} \times 6 \cdot 25)$ ) but the relative values of the different test materials remained almost the same. We are therefore tabulating just the results obtained under the standardized conditions.

\section{DISCUSSION}

\section{Acid Orange 12 binding}

Model materials. Considering first the results shown in Table I for unheated samples with or without added sugars, it appears that Acid Orange 12 has combined in approximately a I:I molar ratio with the reactive basic amino acid groups. Dyebinding values were, in all instances, slightly higher by $\mathrm{I}-7 \%$ than the HARL values and this could have been the result of errors in amino acid analysis and the presence of terminal $\alpha-\mathrm{NH}_{2}$ groups. Under our conditions possible secondary binding mechanisms, such as hydrogen and hydrophobic binding, as suggested by Lakin (1973) appear to have made only a small contribution, unless they are compensating for incomplete primary reactions under the rapid test conditions.

The DBC values for heated BPA and heated chicken muscle also agreed reasonably well with the HARL values. This is consistent with the continued combination of Acid Orange 12 with the total arginine and histidine in the heated samples but only with the portion of lysine units that was also reactive with FDNB. The total lysine values in these samples had fallen very little (Hurrell \& Carpenter, 1974b), as had the arginine and histidine. It follows that there is proportionally less change in the DBC value compared to the reactive-lysine value. With the very severely heated BPA, the dye bound was much less than expected from its HARL value. It may be that in this material arginine and histidine residues have themselves combined with other protein groups or, as is more likely, that the density of neighbouring cross-link formation has prevented the dye penetrating to the potentially reactive sites. Fraenkel-Conrat \& Cooper (1944) found that the dye took longer to reach equilibrium with the highly cross-linked protein of wool than it did with other proteins.

Under the severe heating conditions used to cause protein-protein heat damage it is believed that isopeptide cross-linkages can be formed by condensation between the $\epsilon-\mathrm{NH}_{2}$ group of lysine and the amide groups of glutamine or asparagine (Bjarnason \& 


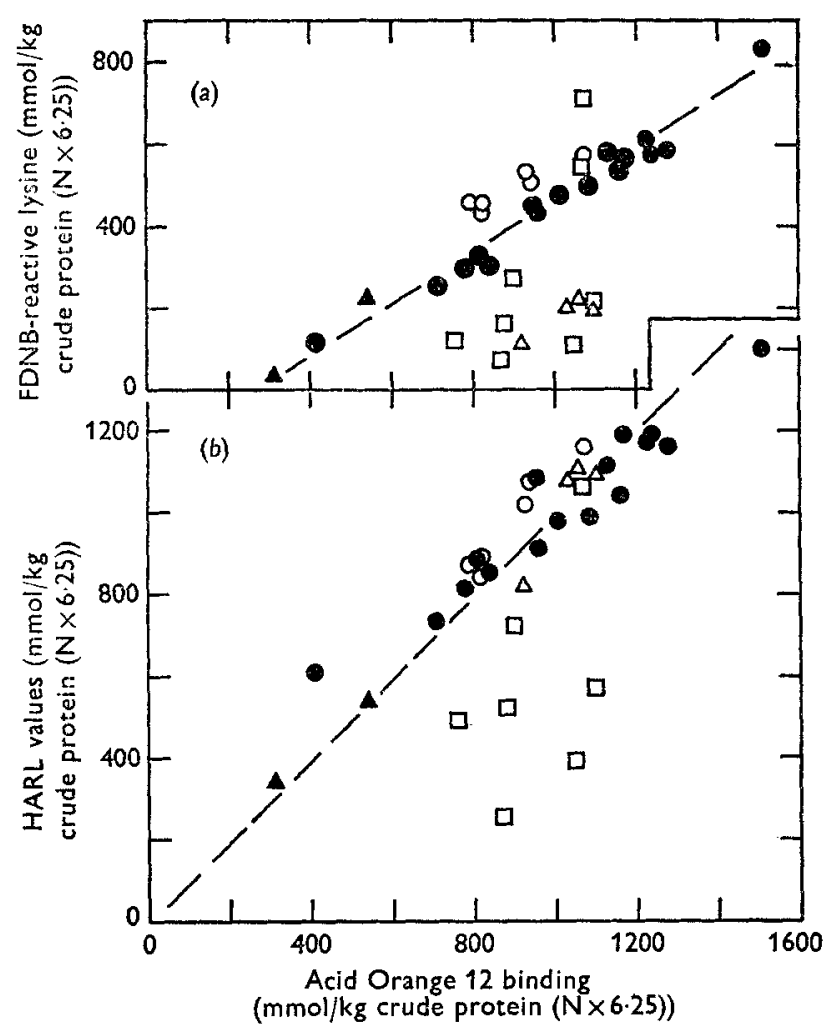

Fig. 2. (a) Relationship between values for Acid Orange 12 binding of test materials (some subjected to heat treatment) and their fluorodinitrobenzene (FDNB)-reactive lysine value. $O$, fish meals;, animal carcass protein preparations; $\triangle$, groundnut meals; $\Delta$, acylated lactalbumin; $\square$, lactalbumin and albumin-sugar mixes; (b) relationship between Acid Orange 12 binding and 'histidine plus arginine and FDNB-reactive lysine' (HARL) values.

Carpenter, 1970). Formyl and propionyl lactalbumin were prepared by these workers as models of a protein in which lysine groups were combined in amide bonds, though these materials did not, of course, contain cross-linkages. Our results show that acylation of lactalbumin had decreased the DBC and the HARL value to approximately the same extent. This indicates that, as expected, the dye does not bind with the lysine $\epsilon-\mathrm{NH}_{2}$ groups which are combined in amide links.

With materials in which Maillard damage had occurred under mild conditions, i.e. glucose-albumin stored for 10 and $30 \mathrm{~d}$ at $37^{\circ}$, dye binding with Acid Orange 12 showed virtually no change although the reactive-lysine content had fallen to 37 and $20 \%$ respectively of the value for the untreated sample, with a corresponding fall in nutritional value in rat and chick assays (Hurrell \& Carpenter, 1974 $b$ ). Lea $\&$ Hannan (1950) have already reported similar results for 'early' Maillard damage. They stored casein with glucose at $37^{\circ}$ and after $5 \mathrm{~d}$ the reactive-lysine content had fallen to $30 \%$ of the value for the untreated sample, whereas the Acid Orange Io binding value had not changed; after $30 \mathrm{~d}$ the reactive-lysine content had fallen to $9 \%$ of the 'untreated' value but the dye-binding value was still $90 \%$ of the 
'untreated' value. With this type of damage the 'early' Maillard products such as fructosyl-lysine (Finot \& Mauron, 1972) still predominate, and it is probable that these are basic in nature and so react with the dye. Arginine and histidine recovered on acid-hydrolysis are also considerably reduced in such materials and yet the DBC is unchanged. Possibly these two amino acid units form complexes with glucose that still bind with the dye but, on acid-digestion of the protein, break down to give reduced yields of the free amino acids. This is what happens with fructosyl-lysine (Finot \& Mauron, 1972).

When protein-glucose or protein-sucrose mixtures were more severely heated, some reduction in DBC resulted, but this was much less than the fall in the reactivelysine content or the HARL value. These materials still contained small amounts of fructosyl-lysine units (Hurrell \& Carpenter, $1974 b$ ) which could combine with the dye and, in addition, some of the 'advanced' Maillard products that they contained may also have been basic.

Animal protein materials. All values for DBC for meat by-products and fish meals (Table 2, Fig. $2 b$ ) were similar to the corresponding HARL values. Non-protein material present, such as fats and minerals, appeared, therefore, to have had little or no effect on their DBC. Although Moran et al. (1963) suggested preliminary solvent extraction of fish meals before dye-binding measurements were made, because they thought that fat might hinder dye penetration, Ashworth (1966, 1971 $a$ ) has reported that fat content had no effect on the DBC of milk, beef and pork proteins.

Even after damage to the meat by-products, the DBC was still close to the corresponding HARL values. This is what we had already found with heated model materials in which the damage was thought to be of the protein-protein type.

The practical interest in using $\mathrm{DBC}$ for quality control of animal products has been as a predictor of available lysine specifically. The relationship between DBC and reactive-lysine is seen in Fig. $2 a$. A single regression line fits the values for all the meat products quite well and further inspection of the results shows that this is due to the range in 'histidine + arginine' values being small in our series of samples compared with the spread of reactive-lysine values.

However, this cannot be expected to apply to feeding-stuffs in general. Typical reported values for seven important food ingredients are tabulated in Table 3 and show that lysine as a proportion of the total basic amino acid content may range from 0.23 to $0.5 \mathrm{I}$. And even within our set of five fish meals the determined 'histidine + arginine' values do range as widely as the 'reactive-lysine' values. Amongst these five samples there is a positive correlation between the two sets of values. There seems no reason for this always to occur, and such differences may account for discrepancies in reports concerning the nutritional significance of $\mathrm{DBC}$ values for fish and meat meals.

Bunyan \& Price (1960) measured the DBC of fish, whale and meat meals with Acid Orange 10 and found over-all positive correlations between these values and nutritional values as measured by animal assay and reactive lysine (Boyne, Carpenter \& Woodham, 196r). Choppe \& Kratzer ( 1963 ) with meat-and-bone meals, and Moran et al. (1963) with fish meals, similarly found positive correlations between Acid Orange ro binding and chick growth, but in all these early investigations values for 
Table 3. Typical values* $($ mmollkg crude protein $($ nitrogen $\times 6.25))$ for basic amino acids in some protein sources

\begin{tabular}{lccc}
\multicolumn{1}{c}{ Total } & $\begin{array}{c}\text { Protein source } \\
\text { lysine }\end{array}$ & Total 'arginine + histidine' & Lysine: lysine + arginine + histidine \\
Fish meal & 530 & 519 & 0.51 \\
Soya bean & 437 & 578 & 0.42 \\
Meat-and-bone meal & 359 & 514 & 0.41 \\
Barley & 236 & 407 & 0.37 \\
Maize & 183 & 816 & 0.31 \\
Cottonseed & 302 & 718 & 0.27 \\
Groundnut & 242 & *FAO (1970). & 0.23 \\
& &
\end{tabular}

some individual samples did not fit the general correlation. Jacobsen, Møller, Nielsen, Schmidtsdorff \& Weidner (1972), with the same improved procedure as ours, applied to Danish fish meals, obtained much better correlations between values for Acid Orange $\mathrm{r} 2$ binding and reactive lysine per unit weight of sample. When the DBC values were expressed in mmol $/ \mathrm{kg}$ crude protein $(\mathrm{N} \times 6.25)$ there was no correlation with reactive lysine (mmol/kg crude protein $(\mathrm{N} \times 6.25)$ ), but quite a good prediction was obtained after subtraction of an empirically determined constant from the original 'DBC' per unit weight of sample.

Sandler (1972) reported that dye binding with Acid Orange I2 after a pretreatment with sodium hydroxide was unsuitable for measuring the protein quality of South African fish meals, as he obtained a correlation coefficient of only 0.437 between dye binding and reactive lysine, each expressed per unit weight of sample. He showed that this could be explained by differences in the relative quantities of the basic amino acids in South African fish meal made from several species of fish and with varying proportions of offal and of soluble concentrate.

A common problem with both dye binding and the direct FDNB-reactive lysine method used here is that hydroxylysine is included in the measurement for lysine. This amino acid cannot replace lysine as a dietary essential and may constitute I2-21\% of the total 'lysine + hydroxylysine' in bone, tendon and skin collagens (Eastoe, 1955); however, the presence of collagens in food will not give a misleading impression that the food is of high quality because even the level of 'lysine + hydroxylysine' in this material is considerably lower than that of lysine in undamaged muscle protein (Carpenter, I960).

Lastly there is the problem with animal (including fish) products that proteolysis may lead to the production of free amino acids which are still of nutritional value but no longer cause dye binding, as measured by precipitation of the dye (J. Schou, personal communication). On the other hand, fission of peptide chains leads to an increase in terminal $\mathrm{NH}_{2}$ groups which will also bind with dyes.

Foods containing carbohydrates. For unheated groundnut meal $(Z, 9)$ there was good agreement between DBC and HARL values although the carbohydrate content was high. Results in Table $\mathrm{r}$ suggest that glucose and sucrose do not interfere with DBC under our conditions. Ashworth ( $197 \mathrm{I} b$ ) reported that starch also does not influence 
dye-binding measurements but Udy (1956) found that $\mathrm{r} g$ starch binds $4.6 \mathrm{mg}$ Acid Orange 10 at $\mathrm{pH} 2 \cdot 2$. This accounted for approximately $17 \%$ of the dye binding in wheat samples with a starch:protein ratio of approximately $5.6: \mathrm{I}$. If, under our conditions, starch had the same relative DBC, then for groundnut meal with a starch: protein ratio of $0.25: \mathrm{I}$, it would account for less than $\mathrm{I} \%$ of the over-all dye binding. Lakin (1973) confirmed that the DBC for Acid Orange I2 with starch was very low.

Results shown in Fig. $2 a$ suggest that even the unheated groundnut meal and the protein isolate have a very different relationship with reactive lysine from that of the animal proteins, but this was only to be expected from the low ratio of lysine: total basic amino acid content of groundnut meal (Table 3 ).

Of the two heat treatments of groundnut, the milder (i.e. $\mathrm{I} h$ at $12 \mathrm{I}^{\circ}$ ) had little effect on any of our values or on the nutritional value of a similar sample (Anantharaman \& Carpenter, 1971). The more severe treatment ( $4 \mathrm{~h}$ at $121^{\circ}$ ) caused a fall of I $40 \mathrm{DBC}$ units $(\mathrm{mmol} / \mathrm{kg}$ crude protein $(\mathrm{N} \times 6.25)$ ) compared with a fall of $290 \mathrm{HARL}$ units. The discrepancy would be explained by the continued binding of the dye to some extent with 'advanced' Maillard compounds of both lysine and arginine. There was previous evidence that such heat treatment caused damage primarily through reactions involving the sucrose present in groundnut meal (Anantharaman $\&$ Carpenter, 1971), and these new results are in line with those obtained with the protein-sucrose models.

Azo dye binding may prove a useful indicator of quality in certain types of oil-seed products, which do have the advantage, compared with animal products, of a more constant amino acid composition of the starting material, but we do not have the evidence here. Moran et al. ( 1963 ) found a useful correlation between DBC and animal growth tests with soya-bean meals. We have not worked with cereal samples but Mossberg (I966) found a correlation between DBC and mouse growth for a series of heated barleys.

Milk powder, which contains lactose, provides the classic example of 'early' Maillard damage on prolonged storage (Henry, Kon, Lea \& White, 1948). Our sample, stored for 29 years, had a DBC value of 880 ; its HARL value was only 520 , compared with a calculated HARL value of 880 (FAO, r970) for undamaged milk powder. Our lower value was due to a $70 \%$ reduction in the reactive-lysine value and it appears that, as with our albumin-glucose samples stored at $37^{\circ}$, the dye binding is unable to detect the serious deterioration in such materials as a source of lysine. Ashworth (1966) found that severe heat treatment during the production of evaporated milk did not reduce the binding of the protein with Acid Orange Io, although this manufacturing process had been shown to reduce the biologically available lysine value of milk by $20 \%$ (Mauron \& Mottu, 1962).

Skurray \& Cumming (1974a, b) have found significant levels of reducing sugars in raw material used for meat-meal production and they suggest that Maillard reactions are responsible for the damage occurring during processing. The above discussion could suggest that such damage would not be measured by dye binding. In our own laboratory-heated meat products (X 823 and X 83I) the Acid Orange I2 values had fallen to the same extent as the HARL values. However, this does not prove that 
only protein-protein damage was involved, as the conditions of heat were much more severe and prolonged ( $5 \mathrm{~h}$ autoclaving at $110^{\circ}$ followed by drying in an air oven at I $60^{\circ}$ for approximately I $8 \mathrm{~h}$ ) than those used to illustrate 'advanced' Maillard damage in our model materials, and the dye may not have been able to penetrate to the reactive sites.

To conclude, it appears that the azo dye procedure used served as an indicator of protein-protein damage, and to some extent of 'advanced' Maillard damage, but that it could only be used for process control where the raw material remained of almost constant basic amino acid composition. It could not be used as an indicator of 'early' Maillard damage.

\section{Remazol blue binding}

This procedure was first used by Ney \& Wirotama (1970) to investigate changes in the reactive-lysine content of heated milk. They observed a decrease in Remazol blue binding when milk was held at $95^{\circ}$ for $30 \mathrm{~min}$ and a further decrease after $2 \mathrm{~h}$, but the dye-binding values they reported were not compared with any direct estimates of reactive lysine. Pruss \& Ney (1972) applied a slightly modified procedure to whey protein but again without using any other procedure for comparison.

Considerable work has been carried out to determine which sites on the protein chain can form covalent links with vinyl sulphone dyes such as Remazol blue, but this has been mainly with wool and under industrial dyeing conditions which include boiling for $\mathrm{I} h$ in a dye bath of changing $\mathrm{pH}$. Under these conditions Asquith \& Chan (197r) found that the functional groups of serine, tyrosine, threonine, cysteine, lysine and histidine all partially reacted with Remazol blue. However, the reaction with reactive dyes is very dependent on the conditions used (Shore, 1968), and under those used by Pruss $\&$ Ney (1972) ( $2.5 \mathrm{~h}$ at $\left.60^{\circ}\right)$, the dye is believed to form covalent links only at the $\epsilon-\mathrm{NH}_{2}$ group of lysine and the thiol group of cysteine. The hydroxyl groups of tyrosine and serine would react if the temperature were increased to $80^{\circ}$ (Ney \& Wirotama, 1970).

We have found that Remazol blue dye-binding values were reduced in heated BPA and heated chicken muscle almost to the same extent as was the reactive-lysine content; these are the materials thought to illustrate protein-protein damage. With albumin-glucose mixes stored at $37^{\circ}$ to produce 'early' Maillard damage, the reduction in $\mathrm{DBC}$ was $60 \%$ of that in reactive lysine, probably because Remazol blue still reacts with some of the 'early' Maillard products and, in addition, with cysteine thiol groups. Lea \& Hannan (I950) found that total cyst(e)ine was much less reduced than reactive lysine when casein-glucose was stored at $37^{\circ}$ for $30 \mathrm{~d}$.

Turning to examples of 'advanced' Maillard damage, with albumin-glucose heated for $\mathrm{I} 5 \mathrm{~min}$ at $\mathrm{I} 2 \mathrm{I}^{\circ}$ and with albumin-sucrose heated for $2 \mathrm{~h}$ at $12 \mathrm{I}^{\circ}$ the proportional decreases in reactive-lysine and $\mathrm{DBC}$ values were similar. This may be explained by cyst(e)ine and reactive lysine having been reduced in similar proportions. With albumin-sucrose heated for $\mathrm{I} h$ at $\mathrm{I} 2 \mathrm{I}^{\circ}$ the $\mathrm{DBC}$ value fell by a greater extent than the reactive-lysine content. This could be explained if cyst(e)ine had been more damaged than lysine. This is a possibility since it has been shown that cyst(e)ine is a heat- 
Table 4. Relationship between values for reactive amino acid groups and the amount of bound Remazol blue (mmol/kg crude protein (nitrogen $\times 6 \cdot 25$ )) in protein

\begin{tabular}{|c|c|c|c|c|c|}
\hline Test material & $\begin{array}{l}\text { FDNB- } \\
\text { reactive } \\
\text { lysine }\end{array}$ & $\begin{array}{l}\text { Reactive } \\
\text { cysteinet }\end{array}$ & $\begin{array}{c}\text { Expected } f \\
\text { reactive } \\
\text { groups }\end{array}$ & $\begin{array}{l}\text { Dye } \\
\text { bound }\end{array}$ & $\begin{array}{l}\text { Dye bound/ } \\
\text { reactive group } \\
\text { (mmol) }\end{array}$ \\
\hline Bovine plasma albumin & & & & & \\
\hline Chicken mus & 612 & 103 & & 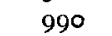 & \\
\hline Albumin mix" & $57 \mathrm{r}$ & 273 & & 1600 & $(I \cdot 90)$ \\
\hline \multicolumn{6}{|c|}{$\begin{array}{l}\text { FDNB, fluorodinitrobenzene. } \\
\text { * Ovalbumin-lactalbumin }(3: 2, w / w) \text {. } \\
\dagger \text { Values for bovine plasma albumin and albumin mix were from Bjarnason \& Carpenter (1970) and } \\
\text { for chicken muscle from Varnish }(197 \mathrm{I}) \text {. These are maximum values, i.e. assuming that all the mole- } \\
\text { cules determined as cysteic acid after performic oxidation and acid-hydrolysis were originally present } \\
\text { in the proteins as cysteine residues, and none as cystine. } \\
\neq \text { Calculated as FDNB-reactive lysine }+ \text { reactive cysteine. }\end{array}$} \\
\hline
\end{tabular}

labile amino acid (Evans \& Butts, 1949; Donoso, Lewis, Miller \& Payne, 1962), and sucrose is damaging to lysine only after its inversion.

Pruss \& Ney (1972) found that the dye bound per $\mathrm{g}$ whey protein varied according to the protein:dye ratio used, and that it could be 2-3 times greater than would be expected from a $\mathrm{I}$ : I combination with lysine units alone. With our fixed protein:dye ratio we obtained similarly high dye-binding values (Table 4 ) and even if all the cys$\mathrm{t}(\mathrm{e})$ ine were present as reactive cysteine units, there is still more dye bound than would correspond to a I: I binding with 'lysine + cysteine' units. Lakin (1973) has pointed out the inevitable impurity of commercial dyestuff preparations, and Remazol blue may also combine, either covalently or electrovalently, with other amino acid groups or even with other dye molecules which have already bound.

For detecting samples with Maillard damage, particularly at an early state for which the Acid Orange I2 procedure was not applicable, Remazol blue appears to be a promising reagent. However, where possible protein-protein damage is under scrutiny it has the disadvantage that, while it is of approximately the same sensitivity as Orange 12, its use at present involves a $7 \mathrm{~h}$ procedure compared with $15 \mathrm{~min}$ for the azo dye.

\section{Cresol red binding}

Frölich (1954) showed that the amount of cresol red bound by soya-bean meals progressively increased as the meals were subjected to more severe heat treatment, i.e. the opposite effect to the action of azo dyes and reactive dyes. He also reported that he could detect heat treatment of rapeseed meal, linseed meal and dried milk, but gave no details. Olomucki \& Bornstein (1960) and Ascarelli \& Gestetner (1962), using Frölich's method, found good correlations between the dye-absorption test and biological trials with chicks for heated soya-bean meals. With soya-bean meals, underheating is as important as overheating since heat treatment is used to destroy the trypsin inhibitors. The nature of the association between phthalein dyes and food materials is not known but Frölich (1954) suggested that products of the Maillard reaction might be responsible for the binding. 
Our results with protein-sugar mixes showed a general increase in dye binding with heat treatment. However, this appeared to relate to 'advanced' Maillard damage rather than to 'early' Maillard damage, and there was no correlation between values for DBC and reactive lysine. Heating protein with sucrose for $2 \mathrm{~h}$ resulted in a lower DBC than heating for $\mathrm{I} h$, i.e. the opposite of the expected effect. With bovine plasma albumin, which is entirely soluble under the conditions of the test there was a negligible loss of dye from solution. With the same protein heated there was dye absorption but progressive heating caused an increase and then a small decrease. With chicken muscle, also used to study protein-protein damage, the changes were very small, and only just significant, but they showed the same tendency.

Our absolute values $(\mathrm{mmol} / \mathrm{kg}$ crude protein $(\mathrm{N} \times 6.25)$ ) for the insoluble protein samples are in the same range as those reported for soya-bean meals, and correspond to only about $2 \%$ of the dye binding with Acid Orange 12 or Remazol blue. Moran et al. (1963) thought that the increased capacity of heated soya-bean meal to bind cresol red was probably due to increased availability of amphoteric groups resulting from increased protein denaturation. Over the early stages of heating, the reaction of cresol red with food proteins may also depend on the solubility of the protein because the dye will only be measured as bound if it is removed from solution. With very severe heat treatment other factors, such as the blocking of reactive sites, may become involved and these could be responsible for the then observed decrease in dye binding. Presumably the studies of Frölich (1954) and others with soya-bean meals were all with samples over the range in which binding was increasing (and almost doubled) with heat. While therefore the procedure has proved useful for quality control specifically in the processing of soya bean, it has not given the same range of values, or consistency of response, with the meat and groundnut products that we have tested.

Finally, to compare the three dye-binding procedures used in this preliminary investigation, the cresol red procedure, as discussed above, appears to have less general application for the detection of heat damage in proteins than do the procedures using Acid Orange 12 or Remazol blue. It would appear that the azo dye binding procedure with Acid Orange 12 can be used for detection of the damage which occurs when proteins are heated severely in the absence of carbohydrates. The reactive dye Remazol blue gives similar results to Acid Orange 12 but is less convenient because the procedure is longer and more complicated. Remazol blue however is more promising for the detection of Maillard damage, particularly that occurring under mild conditions, for which Acid Orange 12 is insensitive. Both these dye-binding procedures need modification if they are to serve specifically as indicators of the level of reactive lysine in foods and more research is needed with materials prepared under commercial processing conditions. The major problem in using Acid Orange 12 for the process control of fish and animal products may be the variation in raw materials used; differences in the arginine and histidine content of these materials can influence the dyebinding value as much as the level of reactive lysine. 
We are indebted to the Agricultural Research Council for a research grant, to A/SN Foss Electric Co., Hillerød, Denmark, for the loan of equipment, and to $\mathrm{Mr}$ A. L. Lakin and Mr J. Schou for reading the manuscript.

\section{REFERENCES}

Anantharaman, K. \& Carpenter, K. J. (I97r). F. Sci. Fd Agric. 22, 4I 2.

Ascarelli, I. \& Gestetner, B. (1962). F. Sci. Fd Agric. 13, 40 I.

Ashworth, U. S. (1966). Y. Dairy Sci. 49, I33.

Ashworth, U. S. (1971 a). F. Fd Sci. 33, 509.

Ashworth, U. S. (197 I b). F. Dairy Sci. 54, 1952.

Ashworth, U. S. \& Chaudry, M. A. (1962). F. Dairy Sci. 45, 952.

Asquith, R. S. \& Chan, D. K. (1971). F. Soc. Dyers Colour. 87, I81.

Atkinson, J. \& Carpenter, K. J. (1970). J. Sci. Fd Agric. 21, 366.

Bjarnason, J. \& Carpenter, K. J. (1969). Br. J. Nutr. 23, 859.

Bjarnason, J. \& Carpenter, K. J. (1970). Br. F. Nutr. 24, 313.

Booth, V. H. (1971). F. Sci. Fd Agric. 22, 658.

Boyne, A. W., Carpenter, K. J. \& Woodham, A. A. (196r). F. Sci. Fd Agric. 12, 832.

Bunyan, J. \& Price, S. A. (1960). F. Sci. Fd Agric. II, 25.

Carpenter, K. J. (1960). Biochem. Y. 77, 604.

Choppe, W. \& Kratzer, F. H. (1963). Poult. Sci. 42, 642.

Donoso, G., Lewis, O. A. M., Miller, D. S. \& Payne, P. R. (1g62). J. Sci. Fd Agric. I3, Igz.

Eastoe, J. E. (1955). Biochem. Y. 6r, 589.

Evans, R. J. \& Butts, H. A. (1949). Science, N.Y. rog, 569.

FAO (1970). Amino Acid Content of Foods and Biological Data on Proteins. Rome: FAO.

Finot, P. A. \& Mauron, J. (1972). Helv. chim. Acta 55, I 53.

Fraenkel-Conrat, H. \& Cooper, M. (1944). F. biol. Chem. 154, 239.

Frölich, A. (1954). Nature, Lond. 174, 879.

Hagberg, A. \& Karlsson, K. E. (1968). FAO/IAEA Pancl for New Approaches to Breeding for Plant Protein Improvement, Rostanga, Sweden, p. I7.

Henry, K. M., Kon, S. K., Lea, C. H. \& White, J. C. D. (1948). F. Dairy Res. 15, 292.

Hurrell, R. F. \& Carpenter, K. J. (1974a). Proc. Nutr. Soc. 33, 13 A.

Hurrell, R. F. \& Carpenter, K. J. (1974b). Br. F. Nutr. 32, 589.

Jacobsen, E. E., Møller, A., Nielsen, J. J., Schmidtsdorff, N. \& Weidner, K. E. (1972). Evaluation of the Dye-Binding Method as a Tool for the Practical Check of Fishmeal Quality. Hillerod, Denmark: A/SN Foss Electric.

Kaul, A. K., Dhar, R. D. \& Raghaviah, P. (1970). J. Sci. Fd Technol. 7, I1.

Lakin, A. L. (1973). In Proteins in Human Nutrition p. I79 [J. W. G. Porter and B. A. Rolls, editors]. London: Academic Press.

Lea, C. H. \& Hannan, R. S. (1950). Biochim. biophys. Acta 5, 433.

Moran, E. T. Jr, Jensen, L. S. \& McGinnis, J. (1963). F. Nutr. 79, 239.

Mauron, J. \& Mottu, F. (I962). J. agric. Fd Chem. ro, 512.

Mossberg, R. (1965). Agric. hort. Genet. 23, 206.

Mossberg, R. (1 966). Agric. hort. Genet. 24, 193.

Mossberg, R. (Ig68). FAO/IAEA Panel for New Approaches to Breeding for Plant Protein Improvement, Rostanga, Sweden, p. I $5^{1}$.

Ney, K. H. \& Wirotama, I. P. G. (1970). Z. Lebensmittelunters. u. -Forsch. 144, 92.

Olomucki, E. \& Bornstein, S. (1960). F. Ass. off. agric. Chem. 43, 440.

Pomeranz, Y. (1965). Y. Fd. Sci. 30, 307.

Pruss, H. D. \& Ney, K. H. (1972). Z. Lebensmittelunters. u. -Forsch. 148, 347.

Roach, A. G., Sanderson, P. \& Williams, D. R. (1967). F. Sci. Fd Agric. 18, 274.

Sandler, L. (1972). Rep. Fishg Ind. Res. Inst., Cape Tn 26, 32.

Shore, J. (r968). \%. Soc. Dyers Colour. 84, 408.

Skurray, G. R. \& Cumming, R. B. (1974a). F. Sci. Fd Agric. 25, 52 I.

Skurray, G. R. \& Cumming, R. B. (1974b). F. Sci. Fd Agric. 25, 529.

Spackman, D. H., Stein, W. H. \& Moore, S. (1958). Analyt. Chem. 3o, $118_{5}$.

Udy, D. C. (1954). Cereal Chem. 31, $3 \circ 9$.

Udy, D. C. (1956). Cereal Chem. 33, I 50.

Varnish, S. A. (197r). Nutritional studies on heat-damaged protein. $\mathrm{PhD}$ Thesis, University of Cambridge. 